\title{
Blandede Grundtvigbolsjer
}

\author{
Af Hans Henrik Hjermitslev
}

Ove Korsgaard og Michael Schelde (red.): Samfundsbyggeren: Artikler om Grundtvigs samfundstcenkning, København: Anis, 2013, 251 sider, 249 kr.

Denne bog udgives på baggrund af en række forskningsprojekter og -konferencer finansieret af Grundtvig Centeret ved Aarhus Universitet. Det er der kommet ni fagfællebedømte artikler ud af, hvoraf de to tidligere er udgivet andetsteds. Det samlende fokus er N. F. S. Grundtvigs rolle som samfundsbygger. Nærmere betegnet hans samfundstænkning og hans betydning for etableringen af Danmark som nationalstat, som velfærdssamfund og danskerne som et oplyst folk i løbet af det 19. århundrede.

Artikelsamlingen er generelt spændende læsning med adskillige originale bidrag; perfekt til ni vinteraftener ved brændeovnen. Men den er også ujævn og mangelfuld i sit indhold, og så savner den en grundig korrektur, særligt af noteapparatet, der tager sig uensartet, mangelfuldt og decideret sjusket ud. Et indeks ville også have forbedret antologiens brugbarhed. Med denne ros og disse forbehold vil vi nu gå i kødet på de ni bidrag.

Ove K. Pedersen lægger ud med artiklen "Tre teser om en legende", hvori han ser nærmere på det paradoks, at Grundtvig hyldes som den vigtigste samfundsbygger i Danmarkshistorien - heraf hans status som legende - men samtidig ignoreres han af den politiske videnskab og den politiske filosofi. Dette råder Pedersen bod på ved at fremsætte tre foreløbige teser om Grundtvigs rolle i den danske stats- og nationsdannelse. Den første tese er, at Grundtvig er en original politisk filosof, der bør tilkendes en plads i den europæiske idéhistorie som en tredje vej mellem radikale oplysningsfilosoffer som Diderot på den ene side og moderate økonomer som Adam Smith på den anden. Som de radikale filosoffer betonede Grundtvig betydningen af folkets dannelse, med Jonathan Israels ord "revolution of the mind", men forblev kritisk over for politisk revolution. På trods af dette lyder Pedersens anden tese, at Grundtvig er revolutionær. Nemlig i den forstand, at han arbejdede for sindets revolution og tog del i den særlige danske udvikling fra enevælde over stænderforsamlinger til folkestyre. Det særlige ved den danske udvikling er, at den fandt sted gennem dannelse og uddannelse af den fjerde stand og gennem reformer og oprettelsen af institutioner til at inddæmme konflikter. Grundtvig var således som politisk leder med til at føre Danmark relativt fredeligt fra absolutisme til folkesuverænitet. Pedersens tredje tese er, at Grundtvig som politisk leder valgte at bygge samfundet som forudsætning for nationen og nationen som forudsætning for 
staten. Dette er enestående i international sammenhæng, hvor nationalismeforskningen typisk har set magt over staten og statsinstitutioner som fx skoler som forudsætningen for skabelsen af national identitet. Grundtvig søgte at bygge nationalstaten fra neden ved først at skabe myndige individer i samfundet, derefter et nationalt fællesskab og til sidst statslige institutioner. Hermed er det også klart, hvorfor Grundtvig er 'samfundsbygger' og ikke blot nationalist eller politiker. Pedersens analyse er skarp og oplysende med dens europæiske udblik, og han falder ikke i den grøft at gøre personen Grundtvig eller forfatteren Grundtvig ansvarlig for udviklingen. Det afgørende er legenden Grundtvig: Det vigtigste for hans indflydelse var de mennesker, der oprettede institutioner og organisationer $\mathrm{i}$ hans navn: "Det er kun, når idealer bliver institutionaliseret, og når de udvikles til organisationer (herunder til højskoler og akademier), at et liv og et værk får indflydelse, og at dens indflydelse kan konstateres" (25). Grundtvigs virkningshistorie er således afgørende for at forstå hans rolle som samfundsbygger. Derfor kan det også undre, at der i antologien ikke er kapitler om netop organisationer og institutioner i Danmark inspireret af Grundtvig. Det kunne have været spændende med analyser af højskolernes, friskolernes og ungdomsforeningernes rolle i Danmarks udvikling, af grundtvigianismens indflydelse på centrale institutioner som folkeskolen og folketinget og af den grundtvigske bevægelses økonomiske betydning for det moderne Danmark.

I stedet får vi i antologiens anden artikel en lang og kyndig eksegese $\mathrm{i}$ "Opfattelser af det nationale - op til og omkring Grundtvig" af Johannes Adamsen. Kapitlet gennemgår Rousseaus, Herders og Fichtes tænkning, "der påvirkede, kunne have påvirket eller præget eller i hvert fald var samtidig med Grundtvig" (31). Så har Adamsen ikke lovet for meget. Og det er netop problemet med kapitlet i en bog om Grundtvig: Adamsen forsøger ikke at vise, hvordan Grundtvig var påvirket af disse udenlandske tænkere bortsat fra en overfladisk analyse til sidst. Man savner svar på basale historiske spørgsmål om, hvad Grundtvig læste, og hvem han refererede til i sine værker. Adamsen kunne have fundet værdifulde svar på disse spørgsmål i Ole Vinds disputats Grundtvigs historiefilosofi, som han end ikke henviser til.

I antologiens tredje artikel er der mere at komme efter, hvis man er interesseret $\mathrm{i}$ at se Grundtvig i en international kontekst. Michael Böss analyserer her Grundtvigs nationalisme på baggrund af international nationalismeforskning. Kapitlet fremstår som en velbegrundet kritik af modernismen, der gennem bl.a. Uffe Østergaards og Ove Korsgaards tidlige værker har været dominerende i Danmark. Inden for den modernistiske skole opfattes nationalisme som et relativt nyt fænomen, der dukker op i 1800-tallet, hvor folk begyndte at føle sig danske. I den forbindelse 
skelner man skarpt mellem 1700-tallets helstatspatriotisme og 1800tallets nationalisme; ofte med en implicit kritik af det etniske og kulturelle element i nationalismen. Ifølge Böss er denne skelnen kunstig, da patriotismen selv dyrkede ideer om fædrelandet, og da dens idé om medborgerskab tog bolig i nationalismen. Kritikere af modernismen har trukket den europæiske nationalismes linjer helt tilbage til middelalderen og påpeget, at en bred national bevidsthed begyndte allerede omkring 1400 med etableringen af kongedømmer i bl.a. Danmark, Sverige og England. Her spillede standardisering af sprogene en vigtig rolle sammen med protestantismens senere kamp for at gøre Biblen tilgængelig på folkesprogene. Böss kaster nyt lys over Grundtvigs nationstænkning ved at analysere ham i lyset af den såkaldte etnosymbolisme og se ham som en vigtig overgangsfigur fra patriotisme til nationalisme, da han gennem sit folkebegreb fornyede og demokratiserede 1700-tallets elitære patriotisme. Han fungerede tillige som det, John Hutchinson kalder 'kulturel nationalist'; en moralsk fornyer, der skaber fælles nationale fortællinger i forbindelse med sociale og politiske omvæltninger og dermed medierer mellem traditionalister på den ene side og modernisatorer på den anden. Det vil sige mellem religiøse konservative og sekulære revolutionære. Böss påpeger således, at Grundtvig og grundtvigianerne spillede en formidlende rolle mellem tradition og modernitet. Böss kritiserer afslutningsvis, i tråd med andre Grundtvigforskere, modernistiske historikere som Søren Mørch, der ganske uhistorisk anklager Grundtvigs folkelighedsbegreb for at være skyld i et påstået dansk snæversyn og fremmedhad.

I antologiens fjerde artikel analyserer Ove Korsgaard klart og overbevisende Grundtvigs bidrag til opbygningen af en ny symbolsk orden. Centralt i denne nye symbolske orden var folket som et nationalt fællesskab. Hermed tog Grundtvig afstand fra Martin Luther og kirkens monopol på dannelse og borgerrettigheder gennem katekismuslæsning og konfirmation. Det nye og afgørende hos Grundtvig var, at fælles sprog og historie, ikke fælles religion, skulle etablere sammenhængskraften i samfundet. Grundtvig sekulariserede således det verdslige regimente, der hos Luther forblev under statskirkens åg. Grundtvig ønskede at skille stat og kirke, så det blev folkets, ikke statens, kirke, som borgerne $\mathrm{i}$ fuld frihed kunne tilslutte sig.

Martin Schwarz Lausten fortsætter antologien med en interessant og lærd artikel om Grundtvigs syn på jødedom og jøder. Lausten placerer på glimrende vis Grundtvigs syn på jøder i dets historiske, litterære og politiske kontekst og analyserer i en række nedslag Grundtvigs opfattelse, der både var kompleks og til tider modsætningsfyldt. Sammenfattende konkluderer Lausten, at Grundtvig havde et relativt positivt syn på sin samtids jøder (med undtagelse af forfatteren Meier Aron Goldschmidt) og særligt på det jødiske folk, som han opfattede som det ypperste, 
men også som det ulykkeligste folk. Grundtvig tog afstand fra datidens antisemitisme og forsvarede jødernes borgerrettigheder på et tidspunkt, hvor jødehadet ellers var udbredt blandt protestantiske teologer som for eksempel Søren Kierkegaard, hvis indædte jødehad Peter Tudvad har dokumenteret i Stadier på antisemitismens vej fra 2010.

Antologiens sjette artikel er et let redigeret genoptryk af Kim Arne Pedersens "Grundtvig, det sociale spørgsmål og velfærdssamfundet" fra 2010. Artiklen er bestemt relevant i en antologi om Grundtvig som samfundsbygger, da den på nuanceret vis får placeret Grundtvig i den politiske debat om fattighjælp i midten af 1800-tallet. I diskussionen af Grundtvigs forhold til socialforsorg og velfærdsstat er der to yderpunkter. På den ene side de, der vil gøre Grundtvig til velfærdsstatens fader ved at citere Grundtvig for 'da har i Rigdom vi drevet det vidt, når få har for meget, og færre for lidt', og på den anden side de, der beskylder Grundtvig for at være en hårdnakket liberalist ved at henvise til hans modstand mod forsørgelsesparagraffen i Grundloven. Pedersen viser, at sandheden ligger et sted imellem. Grundtvig var principiel modstander af offentlig fattigforsorg, der på denne tid primært bestod af arbejdshuse, men samtidig mente han, at gamle, syge og forældreløse børn burde forsørges af det offentlige, og at arbejdsduelige fattige skulle kunne modtage bidrag fra frivillige kirkelige hjælpekasser. Grundlæggende var det Grundtvigs opfattelse, at alle havde ret til rimelige vilkår. Det vil sige ret til jord eller arbejde, så de havde mulighed for at forsørge sig selv. Dette synspunkt stemmer godt overens med Grundtvigs sympati for gårdmændenes kamp for jordreformer omkring 1800, der netop skabte en, i forhold til udlandet, meget homogen gruppe af venstrebønder, hvor få havde for meget og færre for lidt. Det er derfor heller ikke tilfældigt, at mange socialliberale husmænd med tilknytning til Det radikale Venstre og Retsforbundet i første halvdel af 1900-tallet så Grundtvig som en allieret i kampen for jordreformer. Denne virkningshistorie kunne Pedersen med fordel have inddraget mere grundigt $i$ anden halvdel af artiklen, der i stedet består af en række spredte nedslag, der bringer os hastigt hele vejen fra den socialdemokratiske Grundtvigreception og Hal Koch over Galathea 3-ekspeditionen til Dansk Folkeparti, Christine Antorini og Svend Auken.

De tre afsluttende artikler i antologien behandler Grundtvigs virkningshistorie. Inge Adriansen diskuterer, hvordan grundtvigianernes opfattelse af folk og nation i 1800- og 1900-tallet kom til udtryk i bestemte praksisformer. Hun beskriver spændende og kyndigt og med inddragelse af nyere studier af Jes Fabricius Møller og Mette Eriksen Havsteen-Mikkelsen, hvordan former for grundtvigianisme blev udlevet i landbokulturen, og hvordan folkelivet blev symbolsk iscenesat igennem arkitektur, møder og fællessang. Adriansen viser med denne etnologiske tilgang, 
på hvilken måde ideer kan manifestere sig i almindelige menneskers daglige liv. Hun påpeger afslutningsvis: "Den grundtvigske idéverden har man aldrig kunnet sætte på en enkelt formel og slet ikke i nutiden. Der findes ikke som det førhen i en vis grad var tilfældet - en fælles retning og historisk bevidsthed i det sagnomspundne, grundtvigianske fællesskab" (183). De praksisformer, Adriansen beskriver, tilhører en erfaringsverden, der langsomt begyndte at ebbe ud fra 1960'erne, da Danmark gik fra at være et landbrugsland til et industrisamfund og studenteroprørere på højskolerne smed Grundtvig, folket og det nationale på møddingen. Den traditionelle og bevidste grundtvigianisme lever nu videre i valgmenigheder, foredragsforeninger, på nogle af de frie skoler og blandt nærværende tidsskrifts læsere, mens Grundtvigs mere indirekte indflydelse på Danmark stadig afspejler sig i mange af samfundets institutioner.

I antologiens to sidste artikler bevæger vi os til udlandet. Først fortæller Henrik Bredmose Simonsen den fascinerende historie om det grundtvigske miljø i USA. Han beskriver, hvordan danske immigranter fra 1870'erne tog grundtvigianismen med sig over Atlanten. Det udmøntede sig i etableringen af en håndfuld højskoler, der dog alle måtte lukke før 1940, det stadig eksisterende seminarium Grand View College i Iowa og over hundrede spredte menigheder hovedsageligt i Midtvesten. I løbet af 1900-tallet forsvandt det danske sprog fra de grundtvigske kirker, og i 1962 slog den grundtvigske Danske Kirke, der havde brudt med den indremissionske fløj i 1894, sig sammen med andre lutherske kirker. Dermed skulle man tro, at grundtvigianismen forsvandt i USA, men det var ikke tilfældet. Som Simonsen dokumenterer gennem interviews, lever den videre den dag i dag i form af familielejre og ugekurser, bl.a. på den tidligere folkehøjskole Danebod Folk High School i Minnesota, hvor efterkommere af grundtvigske immigranter mødes. Her dyrkes traditionelle discipliner som fællessang, folkedans, gymnastik, kunsthåndværk og foredrag. Den dansksindede fraktion i den amerikanske lutherske kirke udgiver desuden månedsbladet Church and Life, der har omkring 450 abonnenter. Den grundtvigske kristendoms- og livsforståelse i USA er i lighed med den traditionelle grundtvigianisme i Danmark, som Adriansen beskriver, først og fremmest en praksisform i tros- og hverdagsliv: "We lived it, we never put it into words", som en af Simonsens informanter udtrykker det (211). Den amerikanske grundtvigianisme manifesterer sig dog i en række værdier, der kan defineres som socialliberale og som klart venstreorienterede i en amerikansk kontekst, såsom miljøbevidsthed, livslang læring og tolerance i forhold til fx homoseksuelle præster. De amerikanske grundtvigianere er således i opposition til bibelfundamentalistiske protestanter på den kristne højrefløj. Teoretisk trækker Simonsen på David A. Gerbers begreb transnationalisme, der indebærer at europæiske immigranter og efterkommere i USA ikke 
blot blev assimileret, men bibeholdt og udviklede traditioner og praksisformer fra hjemlandet samtidig med, at de blev integreret i det amerikanske samfund.

Urban Claesson afslutter antologien med et komparativt studie af folkekirkens historie i Danmark og Sverige med den sigende titel "Sverige - landet uden Grundtvig". Artiklen er en redigeret version af et arbejde fra 2003, men det er en gave til læserne, at den er taget med her. Gennem komparative analyser som denne er det nemlig muligt at indfange de særlige historiske faktorer, der spillede ind på et lands særegne udvikling. Claesson påviser, at det netop var Grundtvig og hans arvtagere i partiet Venstre, der fik afgørende betydning for forståelsen af folket og for folkekirkens udformning i Danmark. Grundtvigs kirkesyn med fokus på frihed inden for folkekirken i form af bl.a. valgmenigheder, teologen Morten Pontoppidans argumentation for den rummelige folkekirke og politikeren J. C. Christensens arbejde for menighedsrådsloven i 1903 blev afgørende for den decentrale og demokratiske danske folkekirke, der kunne inkludere hele folket. I Sverige blev bondevækkelsen ikke den samme dominerende kulturelle og politiske faktor som i Danmark. Det betød, at kirken i højere grad blev en topstyret statskirke, der ikke tillod valgmenigheder, og som stødte vækkelserne fra sig. Med Claessons ord blev folket kirkens 'subjekt' i Danmark, mens det blev kirkens 'objekt' i Sverige. På den nationale scene blev det i 1900-tallet Socialdemokratiet i Sverige, der definerede folket og nationen, mens det i Danmark var Grundtvig og hans arvtagere, der havde definitionsmagten. Claesson demonstrerer således, at Grundtvig var den helt centrale samfundsbygger inden for folkekirken, mens det efter endt læsning af antologien stadig er et åbent spørgsmål, hvilken rolle han spillede for andre samfundsinstitutioner som folketinget og folkeskolen.

Alt $i$ alt får vi i antologien serveret en gang blandede Grundtvigbolsjer med mange farverige indslag, men også med visse mangler. I 2014 får forskerne omkring Grundtvig Centeret mulighed for at råde bod på dette, når den internationale antologi Building the Nation: Grundtvig and Danish National Identity udkommer. 